\title{
Functional Analysis of the C2A Domain of Synaptotagmin 1: Implications for Calcium-Regulated Secretion
}

\author{
David M. Thomas and Lisa A. Elferink \\ Wayne State University, Department of Biological Sciences, Detroit, Michigan 48202
}

Synaptotagmin 1 is proposed to function as a low affinity calcium sensor for calcium-triggered exocytosis from neural and neuroendocrine cells. Because of the calcium-binding properties of the C2A domain of synaptotagmin 1, calciumdependent interactions through this domain may modulate neurotransmitter release. We addressed this question by using alanine-scanning mutagenesis to generate a series of mutations within the C2A domain of synaptotagmin 1. The effects of these mutations on synaptotagmin $1 \mathrm{C} 2 \mathrm{~A}$ function were analyzed for (1) calcium-dependent phospholipid binding, (2) calcium-dependent binding to syntaxin 1A, a plasma membrane protein critical for vesicle docking or fusion, and (3) calcium-regulated secretion after microinjection into neuroendocrine pheochromocytoma (PC12) cells. Our analyses reveal that a polylysine motif at residues 189-192 confers an inhibitory effect on secretion by recombinant synaptotagmin C2A fragments. The synaptotagmin $1 \mathrm{C} 2 \mathrm{~A}$ polylysine motif functions independently of calcium-mediated interactions with phospholipids and syntaxin 1A. Furthermore, $\alpha$-latrotoxin reverses the inhibitory effect of injected recombinant C2A fragments, suggesting that they perturb the cellular calcium-sensing machinery by interfering with synaptotagmin 1 activity in vivo. Our results indicate that novel calcium-independent interactions mediated through the C2A polylysine motif of synaptotagmin 1 function to modulate neurotransmitter release.

Key words: synaptotagmin; syntaxin; C2A domain; calcium; PC12 cells; phospholipids; calcium-regulated exocytosis
Neural communication requires the regulated release of neurotransmitters at synaptic sites. A unique feature of neural communication is the tight coupling between a local rise in intracellular calcium and the subsequent exocytotic fusion event (DeBello et al., 1993; Südhof and Rizo, 1996). This calcium requirement distinguishes calcium-regulated neurotransmitter release from other exocytotic events and is essential for maintaining the fidelity of synaptic communication. Synaptotagmin 1 is a membrane protein present in all synaptic vesicles and regulated secretory vesicles of neural and neuroendocrine cells. Synaptotagmin 1 is characterized by an intravesicular domain, a single transmembrane domain, and a large cytoplasmic region containing two $\mathrm{C} 2$ domains (C2A and $\mathrm{C} 2 \mathrm{~B}$ ). Several functions have been assigned to the $\mathrm{C} 2$ domains of synaptotagmin 1 . The first $\mathrm{C} 2$ (C2A) domain of synaptotagmin 1 binds negatively charged phospholipids and syntaxin $1 \mathrm{~A}$, a protein implicated in the docking or fusion of secretory vesicles at the plasma membrane (Perin et al., 1990; Davletov and Südhof, 1993; Chapman et al., 1995; Li et al., 1995; Shao et al., 1997). These interactions are calcium dependent. Half-maximal binding of syntaxin 1 A occurs at $\geq 200 \mu \mathrm{m}$ calcium, consistent with the calcium levels required for vesicle fusion (Heidelberger et al., 1994; Li et al., 1995). The structure of the

\footnotetext{
Received Jan. 29, 1998; accepted Feb. 25, 1998.

This work was supported by National Institutes of Health Grant GM53189 (L.A.E.). We thank Drs. Jack Lilien, Kees Elferink, and Mark VanBerkum for critical reading of this manuscript. We thank Drs. Carl Freeman and Shahriar Mobashery for their help with the statistical analysis and molecular imaging, respectively. We thank Dr. Mark Bennett for anti-syntaxin antibodies and Dr. Tom Südhof for a plasmid encoding a GST fusion protein with the C2A domain of synaptotagmin 1 (amino acids 140-267). The technical assistance of Kathleen Vanderpool and Dina Verbeem is greatly appreciated.

Correspondence should be addressed to Dr. Lisa A. Elferink, Wayne State University, Department of Biological Sciences, 5047 Gullen Mall, Detroit, MI 48202.

Copyright (ㄷ) 1998 Society for Neuroscience $\quad 0270-6474 / 98 / 183511-10 \$ 05.00 / 0$
}

synaptotagmin $1 \mathrm{C} 2 \mathrm{~A}$ domain consists of an eight-stranded $\beta$ sandwich fold (termed a $C 2 \mathrm{key}$ ) formed by two four-stranded antiparallel $\beta$ sheets (Sutton et al., 1995) (see Fig. 1). Structural and biochemical studies confirm that calcium binds only to the top of the $\beta$ sandwich, via five clustered aspartic acid residues. Calcium binding does not induce conformational changes in the overall structure of the $\mathrm{C} 2 \mathrm{~A}$ domain. Rather, calcium binding causes a local electrostatic shift in the calcium coordination site, increasing the affinity of the $\mathrm{C} 2 \mathrm{~A}$ domain for effector molecules such as syntaxin 1A (Shao et al., 1996, 1997). The second C2 (C2B) domain of synaptotagmin 1 binds several molecules including syntaxin 1A, brain-specific soluble NSF attachment protein, clathrin AP2, and high inositol polyphosphates (Niinobe et al., 1994; Zhang et al., 1994; Li et al., 1995; Kee and Scheller, 1996). These interactions are calcium independent. The observation that calcium promotes the dissociation of the synaptic vesicle protein $\mathrm{SV} 2$ and the homodimerization of synaptotagmin 1 via its $\mathrm{C} 2 \mathrm{~B}$ domain suggests that the $\mathrm{C} 2 \mathrm{~B}$ domain may also possess calciumdependent properties (Sugita et al., 1996; Schivell et al., 1996). Therefore, because of its calcium-binding properties, synaptotagmin 1 may function as a calcium sensor for neurotransmitter release (Brose et al., 1992).

Functional evidence of synaptotagmin 1 as a calcium sensor comes from genetic and microinjection studies. Transgenic mice and Drosophila mutants defective in synaptotagmin 1 are impaired in neurotransmitter release (Broadie et al., 1994; Geppert et al., 1994; Littleton et al., 1994). In addition, anti-synaptotagmin $1 \mathrm{C} 2 \mathrm{~A}$ antibodies and recombinant $\mathrm{C} 2 \mathrm{~A}$ peptides block neurotransmitter release from injected neuroendocrine pheochromocytoma (PC12) cells, squid giant presynaptic terminals, and adrenal chromaffin cells (Elferink et al., 1993; Mikoshiba et al., 1995; Ohara-Imaizumi et al., 1997) and calcium-stimulated insulin release from permeabilized INS-1 cells (Lang et al., 1997). These 
functional studies coupled with its calcium-binding properties suggest that the calcium-sensing mechanism of synaptotagmin 1 involves the $\mathrm{C} 2 \mathrm{~A}$ domain.

In this paper we examine the role of calcium-dependent and -independent interactions mediated through the synaptotagmin 1 $\mathrm{C} 2 \mathrm{~A}$ domain on neurotransmitter release. Our studies provide compelling evidence that a calcium-independent activity mediated through a polylysine motif in the synaptotagmin $1 \mathrm{C} 2 \mathrm{~A}$ domain is important for neurotransmitter release. Moreover, the C2A polylysine motif functions independently of calciummediated interactions with phospholipids and syntaxin 1A. The implication of these novel calcium-independent properties in exocytosis will be discussed.

\section{MATERIALS AND METHODS}

Materials. All chemicals and reagents were purchased from Sigma (St. Louis, MO) and Fisher Scientific (Houston, TX) unless stated otherwise. Anti-HPC-1 was a gift from Mark Bennett (University of California, Berkeley), and anti-dopamine- $\beta$-hydroxylase (anti-D $\beta \mathrm{H}$ ) was a gift from Ruth Angeletti (Albert Einstein College of Medicine). $\alpha$-Latrotoxin was purchased from Alomone Laboratories (Jerusalem, Israel).

$P C R$. A series of mutations were introduced into a wild-type recombinant synaptotagmin 1 fragment (C2A/SDPYVK) and a nonphospholipid-binding recombinant synaptotagmin fragment (C2A/ SDPAAA). The plasmids encoding these glutathione $S$-transferase (GST)-synaptotagmin $1 \mathrm{C} 2 \mathrm{~A}$ fusion proteins (residues $140-267$ ) have been described previously (Davletov and Südhof, 1993). Using a two-step PCR reaction, we substituted the polylysine residues in the wild-type and the nonphospholipid-binding synaptotagmin $\mathrm{C} 2 \mathrm{~A}$ fragments (amino acids 189-192) with alanines to generate C2A/SDPYVK:AAAA and C2A/SDPAAA:AAAA, respectively. Similarly, substitution of the lysines at residues 189-192 with glutamic acids in the wild-type fragment resulted in the $\mathrm{C} 2 \mathrm{~A}$ domain mutant $\mathrm{C} 2 \mathrm{~A} / \mathrm{SDPYVK}$ :EEEE. For each mutation, the right and left halves of the recombinant fragment were separately amplified with two pairs of oligonucleotides, each consisting of an outside primer and an internal mutagenic primer. Typically, each PCR reaction was performed using $10 \mathrm{ng}$ of template plasmid DNA, 50 pmoles of each primer, $50 \mathrm{~mm} \mathrm{KCl}, 10 \mathrm{~mm}$ Tris-Cl, $\mathrm{pH} 9.0,0.1 \%$ Triton $\mathrm{X}-100,3.0 \mathrm{~mm} \mathrm{MgCl}_{2}, 0.075 \mathrm{~mm}$ each dNTP, and 2.5 units of Taq polymerase (Promega, Madison, WI) in a $100 \mu \mathrm{l}$ volume. A typical cycling reaction consisted of one cycle at $95^{\circ} \mathrm{C}$ for $1 \mathrm{~min}, 55^{\circ} \mathrm{C}$ for $20 \mathrm{sec}$, and $72^{\circ} \mathrm{C}$ for $45 \mathrm{sec} ; 28$ cycles of $95^{\circ} \mathrm{C}$ for $15 \mathrm{sec}, 55^{\circ} \mathrm{C}$ for $20 \mathrm{sec}$, and $72^{\circ} \mathrm{C}$ for $45 \mathrm{sec}$, including a $5 \mathrm{sec}$ increase in the extension time during each extension cycle; and one ending cycle of $95^{\circ} \mathrm{C}$ for $15 \mathrm{sec}, 55^{\circ} \mathrm{C}$ for $20 \mathrm{sec}$, and $72^{\circ} \mathrm{C}$ for $10 \mathrm{~min}$, followed by cooling at $4^{\circ} \mathrm{C}$. The PCR products were purified on an agarose gel, extracted with a Geneclean kit (BIO 101, La Jolla, CA), mixed in equimolar amounts, and reamplified by PCR using the appropriate outside primers. The resulting PCR product was purified, digested with EcoRI and NcoI (New England Biolabs, Beverly, $\mathrm{MA}$ ), and cloned into the expression vector pGEX-KG (Guan and Dixon, 1991). Mutant recombinant fragments containing the single mutation at $\operatorname{Arg} 233$ (C2A/R233Q) or the double mutation with the mutation D230N (C2A/D230N;R233Q) were generated in the wild-type fragment C2A/SDPY V K by two-step PCR. A unique KpnI site in these two constructs was used to exchange the $\mathrm{C}$-terminal sequences containing the single (R233Q) or double (D230N;R233Q) mutation with the wild-type sequence in C2A/SDPYVK:AAAA, generating C2A/AAAA:R233Q and C2A/AAAA:D230N;R233Q, respectively. All PCR fragments were cloned directionally into the unique Bam HI and HindIII sites of the expression vector pGEX-KG. All mutations in the GST fusion clones were confirmed by DNA sequencing.

Purification of GST fusion proteins. Induced expression of GST fusion proteins was performed in Escherichia coli $\mathrm{AB} 1899$ for $4 \mathrm{hr}$ at $37^{\circ} \mathrm{C}$ in bacterial media containing $100 \mu \mathrm{M}$ isopropyl- $\beta$-D-thiogalactopyranoside (IPTG) and a soluble fraction generated using a French press as described previously (Guan and Dixon, 1991). Immobilized synaptotagmin fragments for phospholipid- and syntaxin-binding studies were prepared by incubating $1 \mathrm{ml}$ of the soluble bacterial extract with $1 \mathrm{ml}$ of a $50 \%$ glutathione-agarose bead slurry hydrated in PBS with Tween (PBST: $137 \mathrm{~mm} \mathrm{NaCl}, 2.68 \mathrm{~mm} \mathrm{KCl}, 8.1 \mathrm{mM} \mathrm{Na}_{2} \mathrm{HPO}_{4}, 1.47 \mathrm{mM} \mathrm{KH} \mathrm{PO}_{4}$, and $0.05 \%$ Tween 20 ) at $4^{\circ} \mathrm{C}$ for $1 \mathrm{hr}$ with gentle mixing. Beads were then pelleted at $500 \mathrm{rpm}$ for $1 \mathrm{~min}$, washed five times with $10 \mathrm{ml}$ of PBST, and stored at $4^{\circ} \mathrm{C}$. Soluble recombinant proteins for syntaxin-binding studies and microinjection were purified by glutathione-agarose chromatography and thrombin cleavage, as described previously (Elferink et al., 1993). All samples for microinjection were concentrated by ultrafiltration, dialyzed against microinjection buffer $\left(0.048 \mathrm{M} \mathrm{K}_{2} \mathrm{HPO}_{4}, 0.014 \mathrm{M}\right.$ $\mathrm{NaH}_{2} \mathrm{PO}_{4}, 0.0045 \mathrm{M} \mathrm{KH}_{2} \mathrm{PO}_{4}, \mathrm{pH} 7.2$ ), and stored at $-80^{\circ} \mathrm{C}$ before use. The protein concentration of each sample was determined by either BCA protein assay (Pierce, Rockford, IL) or SDS-PAGE with known quantities of BSA followed by Coomassie blue staining.

Lipid binding. All buffers were prepared in calcium-free water by treating the water with Chelex resin (Bio-Rad, Hercules, CA). CalciumEGTA buffers were prepared using EGTA and a $0.1 \mathrm{M} \mathrm{CaCl}_{2}$ standard solution (VWR, Chicago, IL), and the free calcium concentration was calculated using the Chelator program. Lipid-binding studies were performed as described by Davletov and Südhof (1993) with the following modifications. Typically, $15 \mu \mathrm{g}$ of recombinant synaptotagmin $\mathrm{C} 2 \mathrm{~A}$ immobilized on glutathione-agarose equilibrated in buffer A $(50 \mathrm{~mm}, \mathrm{pH}$ 7.2 , and $0.1 \mathrm{M} \mathrm{NaCl}$ ) was incubated with $17.5 \mu \mathrm{g}$ of ${ }^{3} \mathrm{H}$-labeled liposomes over a range of free calcium concentrations $(0-100 \mu \mathrm{M})$ in a reaction volume of $100 \mu \mathrm{l}$ for $15 \mathrm{~min}$ at room temperature with vigorous shaking. After centrifugation at $500 \mathrm{rpm}$ for $30 \mathrm{sec}$, the supernatant was discarded, and unbound liposomes were removed by washing the beads four times with buffer A, adjusted to the appropriate calcium concentration. The glutathione-agarose beads were transferred to vials, and lipid binding was quantified by liquid scintillation counting.

Syntaxin binding and Western blot analysis. Ten micrograms of recombinant synaptotagmin immobilized to glutathione-agarose beads were incubated for $1 \mathrm{hr}$ at $4^{\circ} \mathrm{C}$ in a $100 \mu \mathrm{l}$ reaction using a range of soluble syntaxin $1 \mathrm{~A}$ concentrations $(1-200 \mu \mathrm{M})$ in buffer B $(10 \mathrm{mM}$ HEPES$\mathrm{NaOH}, \mathrm{pH} 7.4,0.15 \mathrm{M} \mathrm{NaCl}, 2 \mathrm{~mm} \mathrm{MgCl}_{2}, 0.2 \%$ Triton X-100, $0.5 \mathrm{~mm}$ EGTA, and $3 \mathrm{mM} \mathrm{CaCl}_{2}$ ). Glutathione-agarose bound synaptotagminsyntaxin complexes were recovered by brief centrifugation and washed four times with $350 \mu \mathrm{l}$ of buffer $\mathrm{B}$, and the protein complexes were fractionated by SDS-PAGE and transferred to nitrocellulose (Elferink et al., 1993). The filter was blocked for $1 \mathrm{hr}$ at room temperature in buffer $\mathrm{C}$ (15.4 mM NaCl, $10 \mathrm{~mm}$ Tris-Cl, pH 7.4, 5\% dry milk, and $0.1 \%$ Tween 20) and incubated for $1 \mathrm{hr}$ at room temperature with an anti-syntaxin monoclonal antibody (HPC-1) diluted 1:10,000. The blots were washed five times with TBS plus Tween (TBST: $10 \mathrm{~mm}$ Tris-Cl, pH 7.4, 0.09\% $\mathrm{NaCl}$, and $0.01 \%$ Tween 20 ) before incubation in buffer $\mathrm{C}$ with an HRP-conjugated secondary antibody diluted 1:5000 for $1 \mathrm{hr}$ at room temperature. Blots were washed five times with TBST, followed by a single wash in $0.1 \mathrm{M}$ Tris- $\mathrm{Cl}$, $\mathrm{pH} 8.6$, for $10 \mathrm{~min}$. Bound syntaxin was then visualized by enhanced chemiluminescence and autoradiography.

Cell culture and microinjection. Nerve growth factor (NGF)differentiated neuroendocrine PC12 cells were prepared for microinjection by culturing them for $2 \mathrm{~d}$ in matrigel-coated permanox 2 chamber slides in DMEM (Gibco/BRL, Grand Island, NY) supplemented with $2 \%$ FBS, $1 \%$ heat-inactivated HS, and $50 \mathrm{ng} / \mathrm{ml}$ NGF. Microinjection samples were diluted to a working concentration of $0.75 \mu \mathrm{g} / \mu \mathrm{l}$ in microinjection buffer (Elferink et al., 1993) containing $3 \mathrm{mg} / \mathrm{ml}$ Texas Redconjugated dextran 10,000. Microinjections, cell depolarizations, and detection and quantitation of calcium-evoked $\mathrm{D} \beta \mathrm{H}$ surface staining were performed as described previously (Bennett et al., 1993; Elferink et al., 1993). $\alpha$-Latrotoxin-evoked secretion was performed as described previously using a stimulation buffer devoid of $\mathrm{CaCl}_{2}$ and supplemented with $2.2 \mathrm{mM} \mathrm{MgCl}_{2}$ and $5 \mathrm{~mm}$ EGTA (Elferink et al., 1993). Cells were stimulated at $37^{\circ} \mathrm{C}$ for $10 \mathrm{~min}$ with $9.6 \mu \mathrm{M} \alpha$-latrotoxin and fixed and processed for $\mathrm{D} \beta \mathrm{H}$ cell surface staining. Immunofluorescence microscopy was performed using a Zeiss 310 Laser Scanning Microscope (Wayne State University, School of Medicine). Significant differences between control and experimental treatments were determined by contingency table analysis using the Statistical Package for Social Sciences (SPCC Inc.).

\section{RESULTS}

Functional analysis of synaptotagmin $1 \mathrm{C} 2 \mathrm{~A}$ mutants that eliminate calcium-dependent interactions with phospholipids and syntaxin $1 \mathrm{~A}$

The large dense core vesicles (LDCVs) of PC12 cells contain an intravesicular form of the enzyme $\mathrm{D} \beta \mathrm{H}$. We demonstrated previously that the calcium-stimulated fusion of LDCVs with the plasma membrane exposes $\mathrm{D} \beta \mathrm{H}$ immunoreactivity on the cell 

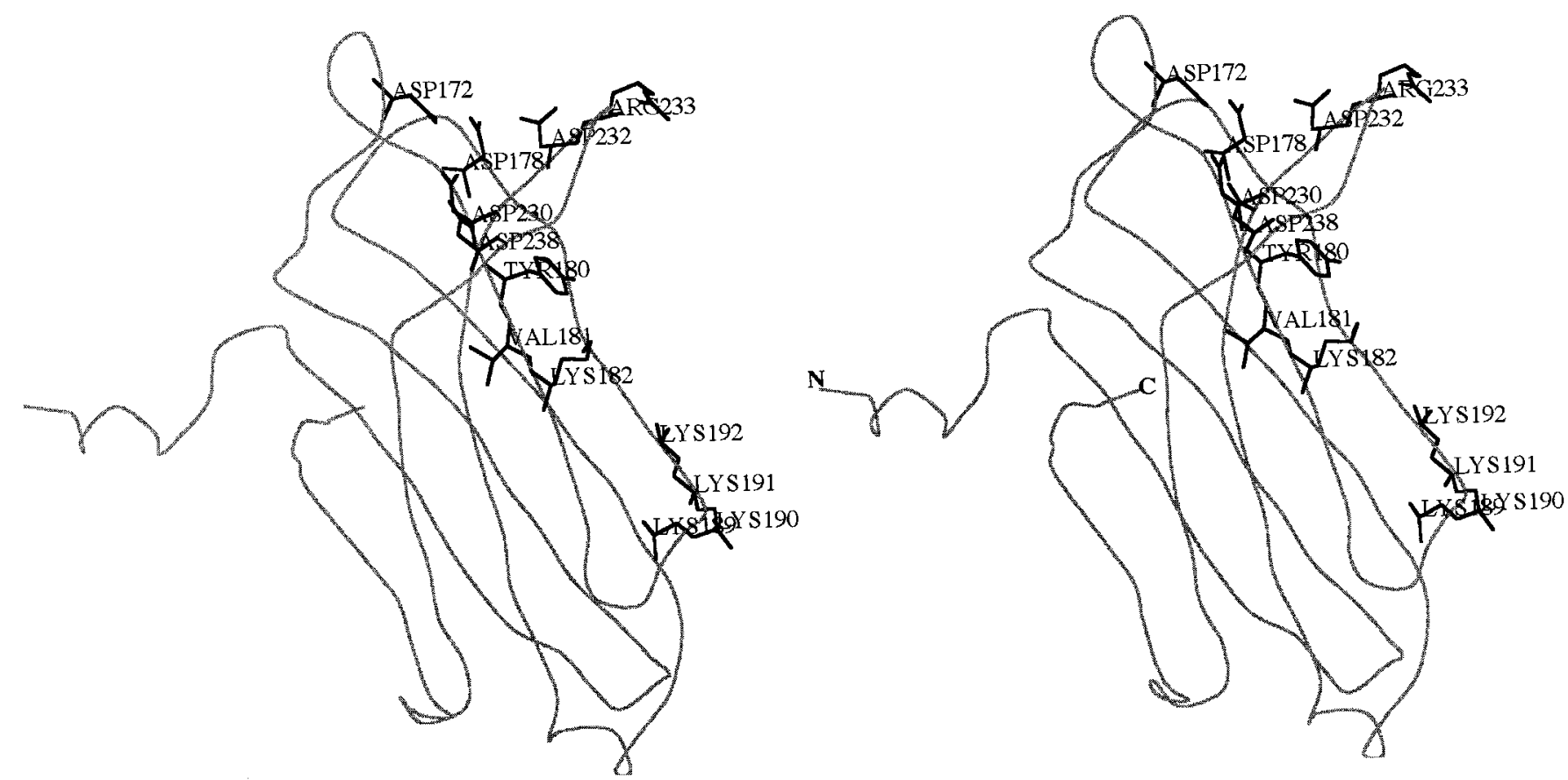

Figure 1. Stereoview of the C2A domain of synaptotagmin 1. $N$ and $C$ terminals of the synaptotagmin $1 \mathrm{C} 2 \mathrm{~A}$ domain (accession number $1 \mathrm{RSY}$ ) are labeled accordingly. The following residues implicated in synaptotagmin 1 function are indicated: residues implicated in phospholipid binding (Tyr180, Val181, and Lys182), five aspartic acid residues coordinating calcium binding (Asp172, Asp178, Asp230, Asp232, and Asp238), Arg233 involved in syntaxin 1A binding, and the C2A polylysine motif (Lys189, Lys190, Lys191, and Lys192).

surface where it can be quantitated by immunofluorescence microscopy (Bennett et al., 1993; Elferink et al., 1993). Using this in vivo secretion assay, we demonstrated that a recombinant synaptotagmin 1 fragment encompassing the C2A domain (residues 96-265) inhibits calcium-regulated exocytosis when microinjected into PC12 cells (Elferink et al., 1993). This recombinant C2A fragment binds negatively charged phospholipids and syntaxin 1A (data not shown). Binding is calcium dependent, suggesting an important role for these interactions in synaptotagmin 1 function. To determine whether the calcium-dependent binding of phospholipids to the recombinant $\mathrm{C} 2 \mathrm{~A}$ fragment was important for its inhibitory effect in our in vivo secretion assay, we prepared mutant recombinant $\mathrm{C} 2 \mathrm{~A}$ fragments designed to perturb these interactions.

Previous in vitro binding studies demonstrated that the $\mathrm{C} 2 \mathrm{~A}$ domain (residues 140-267) of recombinant rat synaptotagmin 1 binds negatively charged phospholipids in a calcium-dependent manner, with an $\mathrm{EC}_{50}$ of $4-6 \mu \mathrm{M}$ free $\mathrm{Ca}^{2+}$ (Davletov and Südhof, 1993). Deletion or mutation of the amino acid motif YVK (residues 180-182) abolishes the ability of recombinant synaptotagmin 1 fragments to bind negatively charged phospholipids (Davletov and Südhof, 1993; Chapman and Jahn, 1994). Structural analysis of the YVK motif reveals that it is located on the concave surface of one of the $\beta$ sheets of the C2A domain (Sutton et al., 1995). The Tyr180 and Lys182 side chains are oriented toward the aqueous milieu, in which they appear to hydrogen bond with crystallographic water molecules on the concave surface of the C2A domain (Fig. 1). Conversely, the side chain of Val181 is buried within the hydrophobic core of the C2A $\beta$ sandwich (Fig. 1). Although a direct role for the YVK motif in calcium-dependent phospholipid binding remains to be established, the biochemical and structural data suggest that mutation of Tyr180 and Lys182 may prevent the phospholipid backbone from associating with the concave surface of the $\beta$ sheet. Alternatively, Tyr180 and Lys182 may function to maintain the conformation of the $\beta$ sandwich, thereby permitting phospholipid binding to the C2A domain (Sutton et al., 1995). Therefore, to determine whether calcium-dependent phospholipid binding is important for the inhibitory effect of recombinant C2A fragments in our in vivo secretion assay, we produced mutant recombinant C2A fragments containing alanine substitutions in the YVK motif (residues 180-182). The effects of these mutations on synaptotagmin 1 function were analyzed for (1) calciumdependent phospholipid binding, (2) calcium-dependent binding to syntaxin 1A, and (3) calcium-stimulated secretion after microinjection into PC12 cells.

For phospholipid-binding studies, each recombinant fragment was expressed as a chimeric GST fusion protein: a wild-type fragment (C2A/SDPYVK), and a mutant fragment containing alanine substitutions in the YVK motif (C2A/SDPAAA). Each GST-C2A fragment was immobilized on glutathione-agarose and incubated with radiolabeled liposomes over a range of free calcium concentrations $(0-100 \mu \mathrm{M})$ to assay for phospholipid binding. The wild-type recombinant $\mathrm{C} 2 \mathrm{~A}$ fragment $\mathrm{C} 2 \mathrm{~A} / \mathrm{SD}$ PYVK bound phospholipids in a calcium-dependent manner, with half-maximal binding observed at $8 \mu \mathrm{M}$ free calcium and displaying a Hill coefficient of 1.8 (Fig. $2 A$ ). Calcium-dependent phospholipid binding was not observed with GST alone or with the recombinant synaptotagmin $\mathrm{C} 2 \mathrm{~A}$ fragment $\mathrm{C} 2 \mathrm{~A} / \mathrm{SDPAAA}$, in which the YVK motif was mutated to AAA (Fig. $2 A$ ). Mutation of both Tyr180 and Lys182 (C2A/SDPAVA) also abolished calcium-stimulated phospholipid binding to recombinant $\mathrm{C} 2 \mathrm{~A}$ fragments (data not shown).

We next examined the ability of each recombinant $\mathrm{C} 2 \mathrm{~A}$ fragment to bind syntaxin $1 \mathrm{~A}$ in vitro. Immobilized recombinant GST-synaptotagmin C2A fragments were incubated with a solu- 


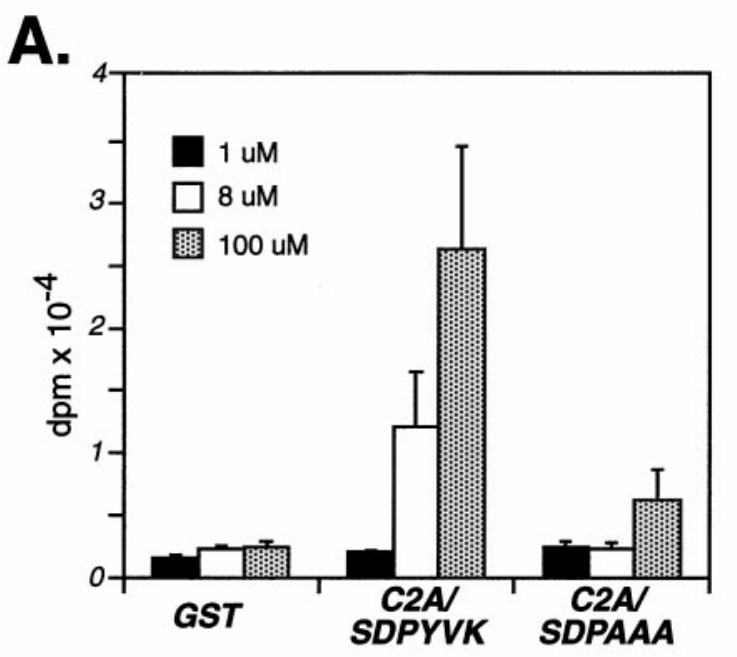

B.

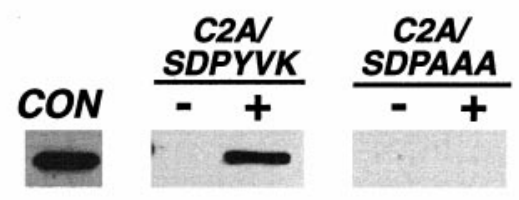

C.

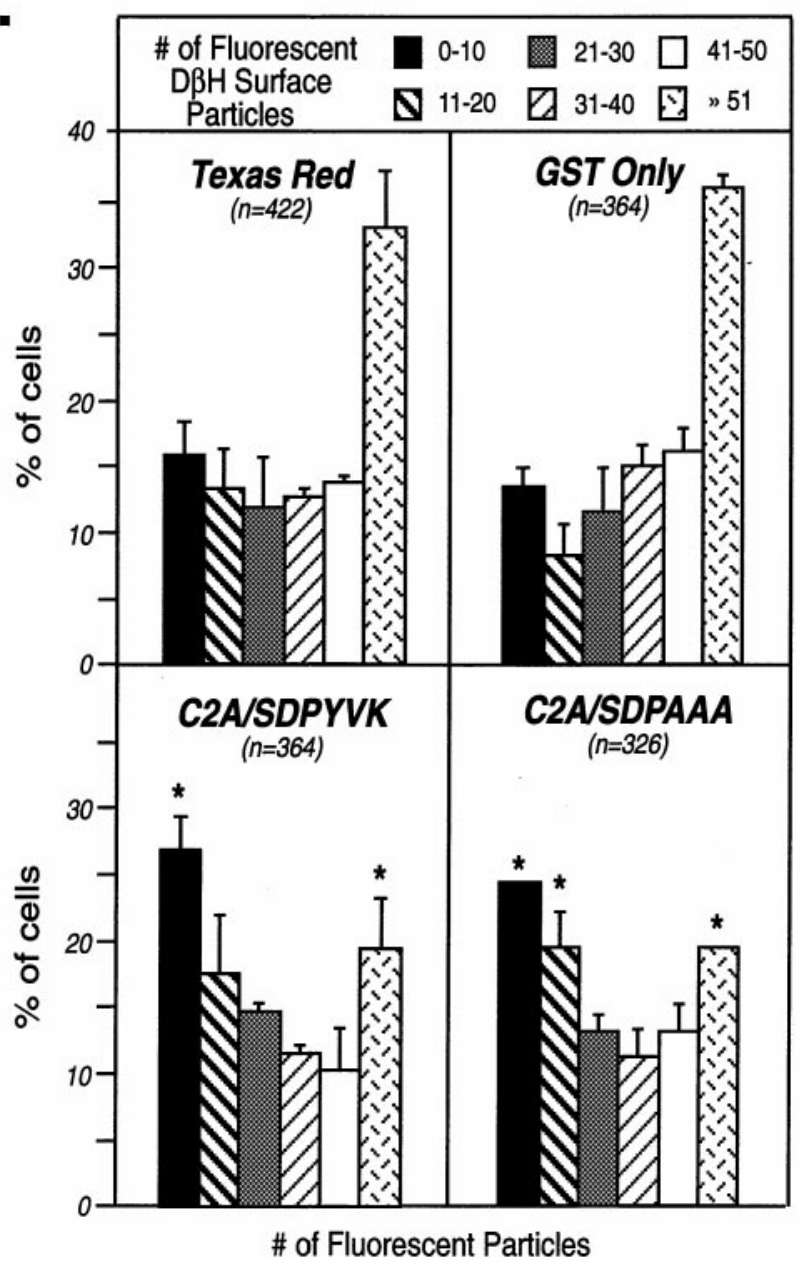

Figure 2. Disruption of phospholipid and syntaxin $1 \mathrm{~A}$ interactions does not reverse the inhibitory effects of C2A fragments on neurotransmitter release. $A$, Recombinant GST and GST-synaptotagmin $1 \mathrm{C} 2 \mathrm{~A}$ proteins (amino acids 140-267) were immobilized to glutathione-agarose and incubated with ${ }^{3} \mathrm{H}$-labeled PC/PS liposomes and $0-100 \mu \mathrm{M}$ free calcium. Phospholipid binding was measured via scintillation counting. The results are plotted as the mean of three individual experiments $\pm \mathrm{SD}$ and as a function of the free calcium concentration at 1,8 , and $100 \mu \mathrm{M}$. $B$, Ten micrograms of the indicated recombinant synaptotagmin $\mathrm{C} 2 \mathrm{~A}$ fragment were incubated with $100 \mu \mathrm{M}$ soluble syntaxin $1 \mathrm{~A}$ in the absence (-) or presence $(+)$ of $3 \mathrm{~mm} \mathrm{CaCl} 2$. Protein complexes were isolated, washed, and analyzed by SDS-PAGE and Western blotting. Syntaxin 1A binding was detected using the anti-syntaxin antibody HPC-1 and enhanced chemiluminescence. Seventy-five micromolar fractionated soluble syntaxin 1A (Con) was used as a Western control. No binding was observed using GST-conjugated beads (data not shown). C, NGF-differentiated PC12 cells were coinjected with Texas Red-conjugated dextran and the indicated soluble recombinant synaptotagmin fragments at a final protein concentration of $0.75 \mu \mathrm{g} / \mu \mathrm{l}$. Control cells were injected with Texas Red-conjugated dextran only (Texas Red) or coinjected with a control GST extract (GST Only). One hour after microinjection, the cells were $\mathrm{K}^{+}$ depolarized, and $\mathrm{D} \beta \mathrm{H}$ surface immunoreactivity was detected with a fluorescein-labeled secondary antibody. The numbers of individual $\mathrm{K}^{+} / \mathrm{Ca}^{2+}{ }_{-}$ mediated D $\beta \mathrm{H}$ fluorescent patches were counted, regardless of their size, and are presented as a percent of the total number of cells injected. Data are shown as the mean of two independent experiments $\pm \mathrm{SD}$ with the total number of injected cells $n$. Significant differences $\left(p \leq 0.01, \chi^{2}\right.$ analysis $)$ between experimental and control treatments are indicated with an asterisk.

ble recombinant fragment encompassing the cytoplasmic domain of syntaxin 1A (amino acids 4-266), followed by immunological detection of bound syntaxin $1 \mathrm{~A}$ (Fig. $2 \mathrm{~B}$ ). The wild-type C2A fragment $\mathrm{C} 2 \mathrm{~A} / \mathrm{SDPYVK}$ binds syntaxin $1 \mathrm{~A}$ in a calciumdependent manner. No binding is detected with the nonphospholipid-binding mutants C2A/SDPAAA (Fig. 2B) or C2A/SDPAVA (data not shown) in either the absence or presence of calcium. These data indicate that mutation of the YVK motif also disrupts calcium-dependent binding of syntaxin $1 \mathrm{~A}$ to recombinant synaptotagmin $1 \mathrm{C} 2 \mathrm{~A}$ fragments in vitro.

To determine if the YVK motif is required for the inhibitory effects of microinjected recombinant $\mathrm{C} 2 \mathrm{~A}$ fragments, we compared the effects of microinjected wild-type and mutant synaptotagmin 1 fragments on calcium-regulated secretion. Microinjec- tion studies were performed on NGF-differentiated PC12 cells, and calcium-regulated secretion was monitored by $\mathrm{D} \beta \mathrm{H}$ cell surface staining. Quantitative analysis of the secretion assay reveals high levels of $\mathrm{D} \beta \mathrm{H}$ cell surface staining ( $\geq 51$ fluorescent patches) on $30-40 \%$ of control uninjected cells (data not shown) and cells injected with Texas Red-conjugated dextran only or a control GST extract (Fig. 2C). Conversely, microinjection of either the wild-type synaptotagmin fragment C2A/SDPYVK or the nonphospholipid/syntaxin 1A-binding mutant C2A/SDPAAA results in a significant reduction in calcium-regulated secretion from PC12 cells. Similarly, microinjection of a nonphospholipid/ syntaxin 1A-binding C2A fragment containing alanine substitutions in Tyr180 and Lys182 (C2A/SDPAVA) also elicits a comparable reduction in calcium-regulated secretion (data not 
shown). These results indicate that calcium-dependent interactions involving the YVK motif are not responsible for the inhibitory effects of recombinant $\mathrm{C} 2 \mathrm{~A}$ fragments on calcium-regulated secretion from injected PC12 cells.

\section{Functional analysis of synaptotagmin 1 mutations that eliminate calcium binding}

Our above data demonstrate that alanine substitution of the YVK motif disrupts the calcium-stimulated binding of synaptotagmin 1 $\mathrm{C} 2 \mathrm{~A}$ fragments to recombinant syntaxin $1 \mathrm{~A}$ but fails to reverse the inhibitory effect of these $\mathrm{C} 2 \mathrm{~A}$ fragments on regulated secretion from PC12 cells. To confirm that the inhibitory effects of our microinjected $\mathrm{C} 2 \mathrm{~A}$ fragments involve interactions distinct from calcium binding and syntaxin $1 \mathrm{~A}$ interactions, we prepared additional mutant recombinant $\mathrm{C} 2 \mathrm{~A}$ fragments designed to perturb these specific interactions. Nuclear magnetic resonance (NMR) spectroscopy in combination with site-directed mutagenesis identified five aspartic acids (residues 172, 178, 230, 232, and 238) important for coordinating calcium binding to the C2A domain of synaptotagmin and an arginine residue (position 233) implicated in syntaxin 1A interactions (Sutton et al., 1995; Shao et al., 1996, 1997). Mutation of one aspartic acid residue at position 230 (D230N; see Fig. 1) impairs the binding of calcium to the C2A domain of synaptotagmin in vitro. Mutation of the arginine residue at position 233 (R233Q) reduces calcium-dependent binding of syntaxin $1 \mathrm{~A}$ to the $\mathrm{C} 2 \mathrm{~A}$ domain of synaptotagmin 1 in vitro (Shao et al., 1997) (see Fig. 1). We prepared recombinant C2A fragments containing the single mutation at Arg233 (C2A/ $\mathrm{R} 233 \mathrm{Q})$ and a double mutant (C2A/D230N;R233Q). The functional consequences of these mutations were analyzed by examining syntaxin 1A interactions and calcium-regulated exocytosis after microinjection into PC12 cells.

As expected, these mutations abolished calcium-dependent binding of each recombinant $\mathrm{C} 2 \mathrm{~A}$ fragment to syntaxin $1 \mathrm{~A}$ (Fig. $3 A$ ). In our in vivo secretion assay, injection of $\mathrm{C} 2 \mathrm{~A} / \mathrm{R} 233 \mathrm{Q}$ or $\mathrm{C} 2 \mathrm{~A} / \mathrm{D} 230 \mathrm{~N} ; \mathrm{R} 233 \mathrm{Q}$ results in reduced levels of $\mathrm{D} \beta \mathrm{H}$ surface staining, comparable with that in cells injected with the wild-type fragment (compare Figs. 3B, 2C). Cells injected with either Texas Red alone or control GST preparations gave control levels of $\mathrm{D} \beta \mathrm{H}$ cell surface staining similar to that in uninjected cells (data not shown). Thus several different mutations that disrupt calcium binding and calcium-dependent syntaxin $1 \mathrm{~A}$ binding to the $\mathrm{C} 2 \mathrm{~A}$ domain of synaptotagmin 1 do not reverse the inhibitory effect of microinjected $\mathrm{C} 2 \mathrm{~A}$ fragments on calcium-regulated secretion from PC12 cells.

\section{Identification of a new functional motif within the synaptotagmin 1 C2A domain}

One explanation for the block in calcium-regulated secretion observed with recombinant $\mathrm{C} 2 \mathrm{~A}$ fragments that do not bind calcium, phospholipids, or syntaxin $1 \mathrm{~A}$ is that their inhibitory effect is mediated by other regions within the $\mathrm{C} 2 \mathrm{~A}$ domain. However, it is possible that the inhibitory effect of recombinant C2A fragments occurs via a mechanism distinct from the normal cellular secretory machinery. We performed a series of experiments to distinguish between these two possibilities.

To determine whether the microinjected recombinant $\mathrm{C} 2 \mathrm{~A}$ fragments interfere with the normal sequence of steps leading to neurotransmitter release, we used $\alpha$-latrotoxin, a potent neurotoxin from black widow spider venom (Rosenthal et al., 1990). $\alpha$-Latrotoxin is proposed to trigger neurosecretion by binding to two types of cell surface receptors (neurexin $1 \alpha$ and CIRL/

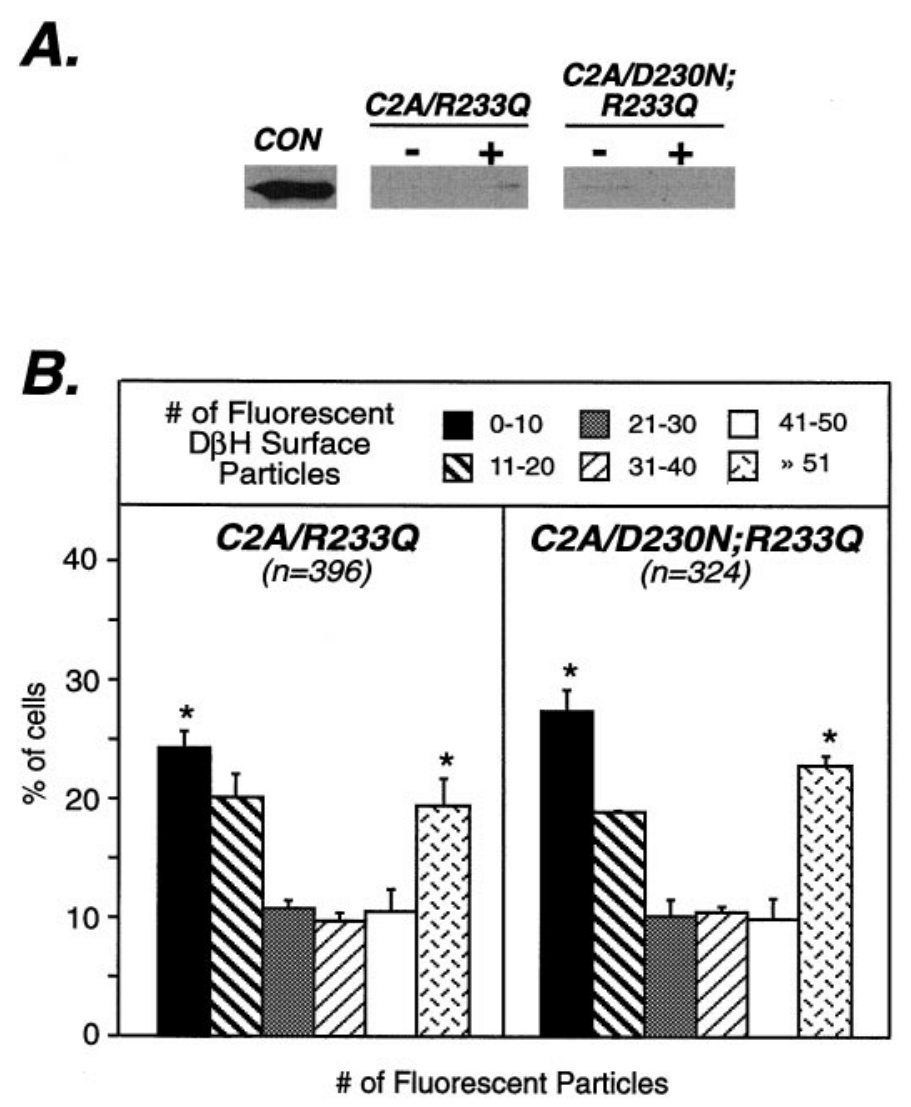

Figure 3. Calcium and syntaxin $1 \mathrm{~A}$ binding are not responsible for the inhibitory effect of soluble synaptotagmin $1 \mathrm{C} 2 \mathrm{~A}$ fragments on calciumregulated secretion. $A$, Ten micrograms of each indicated recombinant synaptotagmin $\mathrm{C} 2 \mathrm{~A}$ fragment were immobilized on glutathione-agarose and incubated with $100 \mu \mathrm{M}$ soluble syntaxin 1A in the absence (-) or presence $(+)$ of $3 \mathrm{mM} \mathrm{CaCl}{ }_{2}$. Syntaxin $1 \mathrm{~A}$ binding was detected by immunoblotting as described in the legend to Figure $2 B$. Seventy-five micromolar soluble syntaxin $1 \mathrm{~A}$ was used as a Western control $(C o n) . B$, NGF-differentiated PC12 cells were coinjected with Texas Red and the indicated soluble recombinant synaptotagmin fragment at a final concentration of $0.75 \mu \mathrm{g} / \mu \mathrm{l}$ and were processed as indicated in the legend to Figure $2 C . \mathrm{D} \beta \mathrm{H}$ staining was quantitated and is presented as the mean of two to three separate experiments $\pm \mathrm{SD}$ with the total number of injected cells $n$. Significant differences ( $p \leq 0.01$, chi-square analysis) between experimental and control treatments are indicated with an asterisk.

latrophilin), which differ in their requirement for calcium binding (Hata et al., 1993; Krasnoperov et al., 1997; Lelianova et al., 1997). Whereas a role for neurexin $1 \alpha$ in neurotransmitter release remains to be determined, CIRL and $\alpha$-latrotoxin interactions in adrenal chromaffin cells seem to trigger secretion through the normal secretory apparatus. Thus, $\alpha$-latrotoxin can bypass the calcium requirement for vesicle fusion and directly trigger neurotransmitter release. We assessed the ability of $\alpha$-latrotoxin to override the inhibitory effect of the recombinant $\mathrm{C} 2 \mathrm{~A}$ fragments on neurotransmitter release from injected PC12 cells. We hypothesized that if microinjected recombinant $\mathrm{C} 2 \mathrm{~A}$ fragments were functioning to perturb the normal secretory machinery, $\alpha$-latrotoxin would bypass their inhibitory effect in our in vivo secretion assay. To test this hypothesis, we injected NGFdifferentiated PC12 cells with Texas Red either alone or with a recombinant wild-type $\mathrm{C} 2 \mathrm{~A}$ fragment, and their effects on $\alpha$-latrotoxin-triggered secretion was quantitated by immunofluorescence microscopy $1 \mathrm{hr}$ after injection (Fig. 4). In the absence of calcium and $\alpha$-latrotoxin treatment, minimal $\mathrm{D} \beta \mathrm{H}$ cell surface 


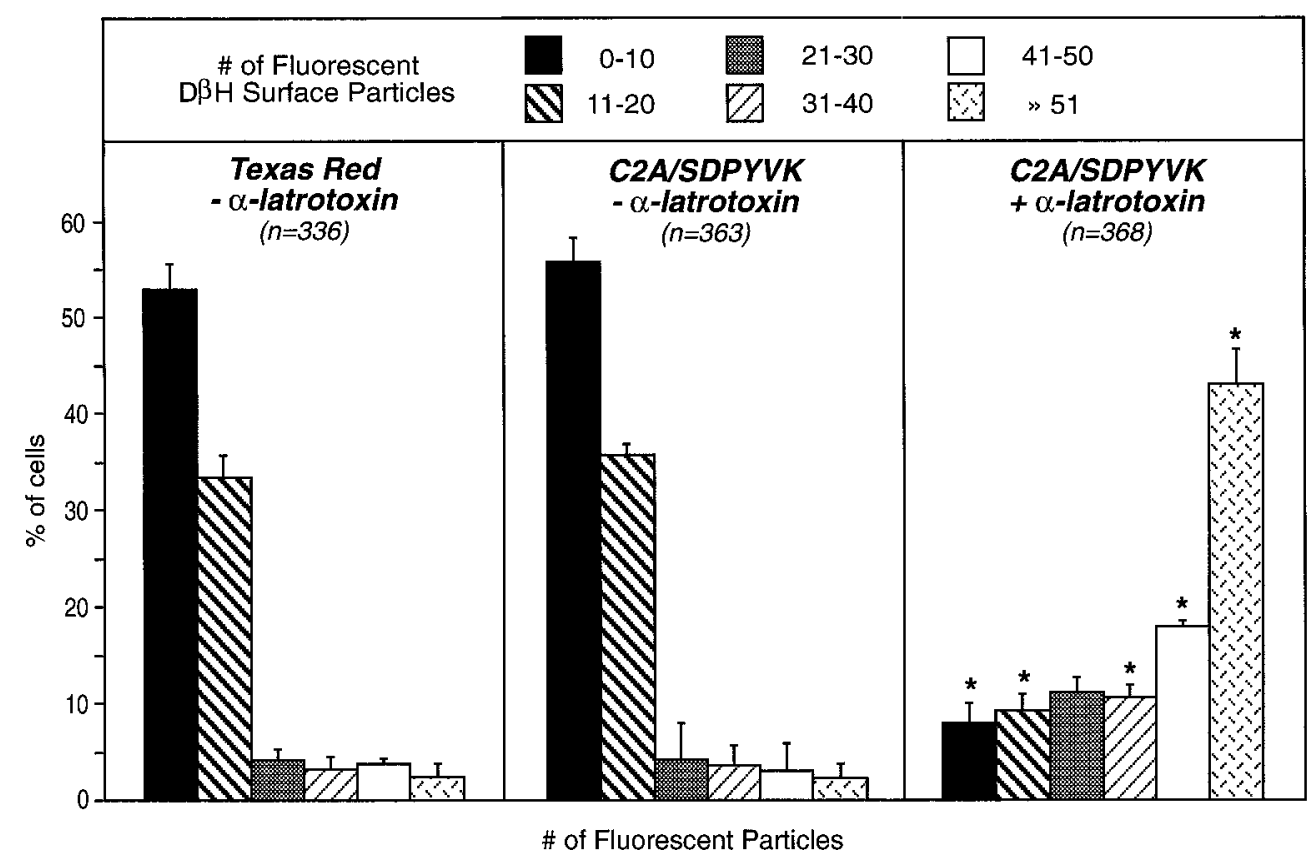

Figure 4. $\alpha$-Latrotoxin reverses the inhibitory effect of soluble synaptotagmin C2A fragments on calcium-regulated secretion. NGF-differentiated PC12 cells were injected with Texas Red either alone or with the indicated soluble recombinant synaptotagmin fragment at a final protein concentration of $0.75 \mu \mathrm{g} / \mu \mathrm{l}$. One hour after injection, the cells were depolarized in a calcium-free buffer supplemented with $2.2 \mathrm{mM} \mathrm{MgCl}_{2}, 5 \mathrm{mM}$ EGTA, with or without $\alpha$-latrotoxin. $\mathrm{D} \beta \mathrm{H}$ staining was quantitated and is presented as the mean of two to three separate experiments \pm SD with the total number of injected cells $n$. Significant differences ( $p \leq 0.01$, chi-square analysis) between experimental and control treatments are indicated with an asterisk.

staining was observed on $50-60 \%$ of control cells injected with Texas Red either alone or with the wild-type fragment C2A/ SDPYVK. Conversely, $\alpha$-latrotoxin treatment of cells injected with C2A/SDPYVK abolished the inhibitory effect of this recombinant $\mathrm{C} 2 \mathrm{~A}$ fragment and triggered calcium-independent neurotransmitter release, as indicated by an increase to $40-50 \%$ of cells with maximal $\mathrm{D} \beta \mathrm{H}$ cell surface staining (Fig. 4). These data demonstrate that the recombinant synaptotagmin $1 \mathrm{C} 2 \mathrm{~A}$ fragment specifically inhibits neurotransmitter release from PC12 cells by interfering with the endogenous cellular secretory machinery.

To investigate the possibility that the inhibitory effects of the recombinant $\mathrm{C} 2 \mathrm{~A}$ fragments may be mediated by other regions within the $\mathrm{C} 2 \mathrm{~A}$ domain, we first compared the peptide sequences of C2A domains from several synaptotagmin isoforms. Seven synaptotagmin isoforms contain a highly conserved region of four consecutive basic amino acids, toward the $\mathrm{C}$ terminal from the YVK motif. In synaptotagmin 1, this motif is composed of four lysines (termed a polylysine motif) at residues 189-192. The high conservation of this motif among synaptotagmin isoforms, coupled with the absence of an analogous motif in other C2containing proteins including protein kinase $\mathrm{C} \alpha$, rabphillin, and DOC proteins, suggests that the $\mathrm{C} 2 \mathrm{~A}$ polylysine motif may be functionally important for synaptotagmin 1 activity (Coussens et al., 1986; Li et al., 1994; Orita et al., 1995). In keeping with this hypothesis, microinjection of a 15 residue synthetic peptide encompassing the $\mathrm{C} 2 \mathrm{~A}$ polylysine motif of synaptotagmin 1 blocks neurotransmitter release from the squid giant axon, whereas microinjection of a randomized peptide with the same lysine content fails to block secretion from squid giant axons (Bommert et al., 1993). These data suggest that the peptide sequence per se rather than its high lysine content is responsible for the inhibitory effect on neurotransmitter release. Finally, structural studies on synaptotagmin 1 reveal that the $\mathrm{C} 2 \mathrm{~A}$ polybasic motif is exposed on the surface of the $\beta$ sandwich, where it is accessible to potential effector molecules (Sutton et al., 1995). Collectively, these data suggest that the $\mathrm{C} 2 \mathrm{~A}$ polylysine motif may be functionally important for synaptotagmin 1 activity.

To determine whether the inhibitory effect of recombinant $\mathrm{C} 2 \mathrm{~A}$ fragments is mediated through the polylysine motif, we prepared a series of recombinant fragments containing alanine substitutions in this region. These include recombinant $\mathrm{C} 2 \mathrm{~A}$ fragments containing alanine substitutions of the polylysine (KKKK) motif at residues 189-192 (C2A/SDPYVK:AAAA) and of the polylysine motif and the YVK motif at residues 180-182 (C2A/SDPAAA:AAAA) and a C2A fragment in which the KKKK motif at residues 189-192 was replaced with glutamic acid residues (C2A/SDPYVK:EEEE). Each fragment was expressed as a GST fusion protein, and their functional properties analyzed for calcium-stimulated syntaxin 1A binding, phospholipid binding and by microinjection into PC12 cells.

As shown in Figure $5 A$, calcium-dependent syntaxin $1 \mathrm{~A}$ binding occurs with C2A/SDPYVK:AAAA and C2A/SDPYVK: EEEE. No syntaxin 1A binding is observed with C2A/SDPAAA: AAAA (Fig. $5 A$ ) or GST only (data not shown) in the presence or absence of calcium. In phospholipid-binding studies, $\mathrm{C} 2 \mathrm{~A} /$ SDPYVK:AAAA and C2A/SDPYVK:EEEE display binding profiles comparable with those of the wild-type fragment $\left(\mathrm{EC}_{50}\right.$ for free calcium of 8 and 10-20 $\mu \mathrm{M}$, respectively; data not shown), whereas calcium-dependent phospholipid binding is abolished with the nonsyntaxin-binding fragment C2A/SDPAAA:AAAA (data not shown). The retention of calcium-dependent syntaxin and phospholipid binding to $\mathrm{C} 2 \mathrm{~A}$ fragments containing mutations in the polybasic KKKK motif suggests that mutations in the polylysine motif do not perturb the highly ordered structure of the 


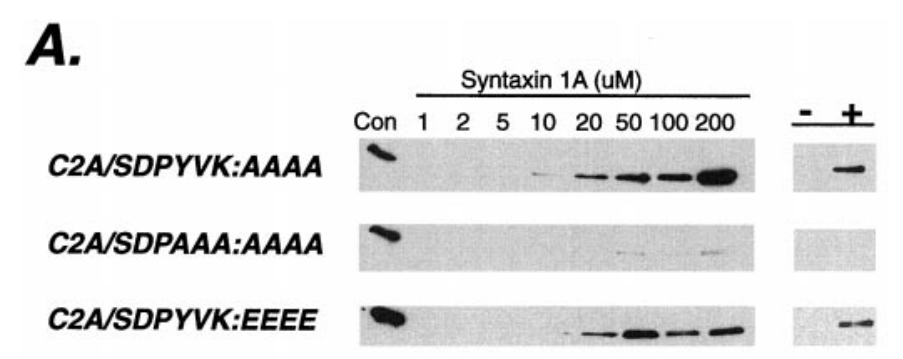

B.

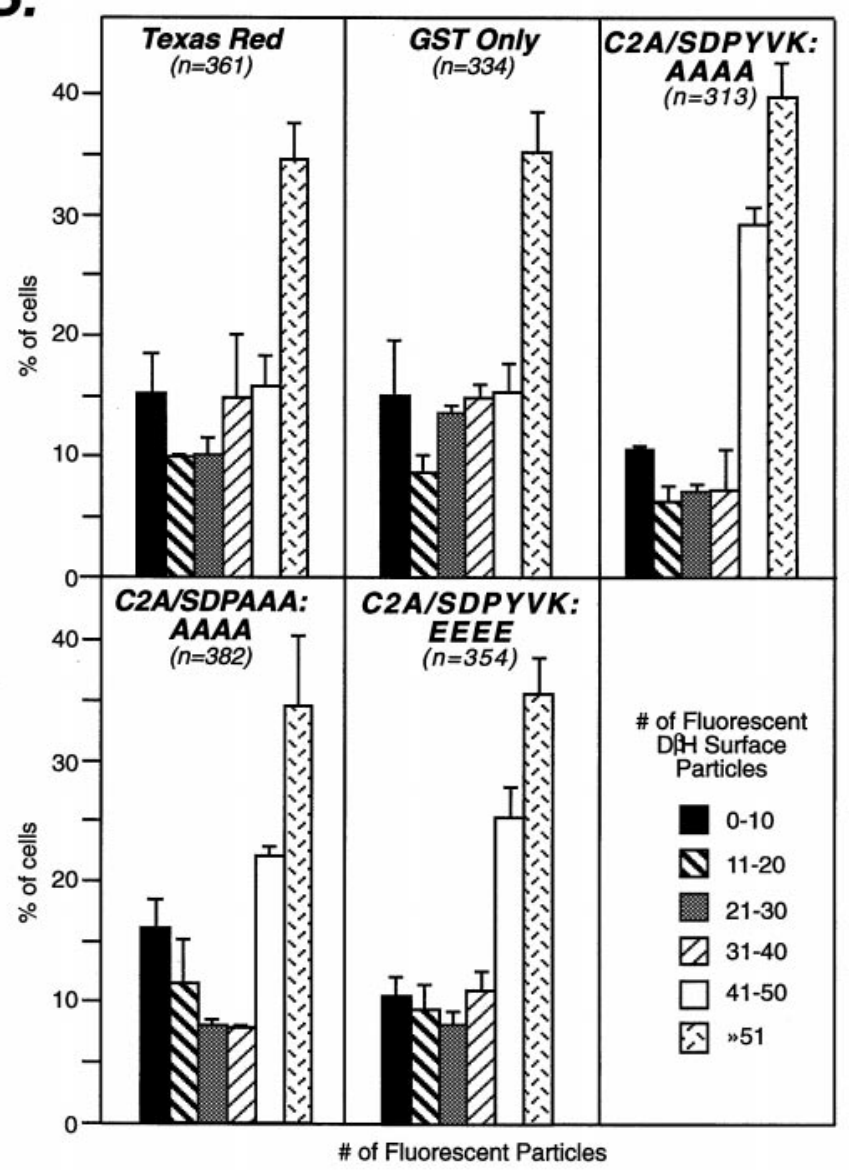

Figure 5. The polylysine motif is essential for synaptotagmin 1 function in vivo. $A$, Ten micrograms of each indicated recombinant synaptotagmin $\mathrm{C} 2 \mathrm{~A}$ fragment were immobilized on glutathione-agarose and incubated with $0-200 \mu \mathrm{M}$ soluble syntaxin $1 \mathrm{~A}$ in the presence of $3 \mathrm{~mm} \mathrm{CaCl}_{2}$. The calcium dependency of this interaction was examined by incubating $10 \mu \mathrm{g}$ of each indicated recombinant synaptotagmin $\mathrm{C} 2 \mathrm{~A}$ fragment immobilized on glutathione-agarose with $100 \mu \mathrm{M}$ soluble syntaxin $1 \mathrm{~A}$ in the absence $(-)$ or presence $(+)$ of $3 \mathrm{mM} \mathrm{CaCl}_{2}$. Syntaxin $1 \mathrm{~A}$ binding was detected by immunoblotting as described in the legend to Figure $2 B$. Seventy-five micromolar soluble syntaxin $1 \mathrm{~A}$ was used as a Western control (Con). B, NGF-differentiated PC12 cells were coinjected with Texas Redconjugated dextran and the indicated soluble recombinant synaptotagmin fragments at a final protein concentration of $0.75 \mu \mathrm{g} / \mu \mathrm{l}$. Control cells were injected with Texas Red-conjugated dextran only (Texas Red) or coinjected with GST extract only (GST Only). The numbers of individual $\mathrm{K}^{+} / \mathrm{Ca}^{2+}$-mediated $\mathrm{D} \beta \mathrm{H}$ fluorescent patches were counted, regardless of their size, and are presented as a percent of the total number of cells injected. Data are shown as the mean of two independent experiments \pm $\mathrm{SD}$ with the total number of injected cells $n$. No statistically significant differences were observed between experimental and control treatments ( $p>0.01$, chi-square analysis).
C2A calcium-binding cavity and that they are well-folded calcium-binding proteins.

Microinjection of recombinant $\mathrm{C} 2 \mathrm{~A}$ fragments containing mutations in the C2A polylysine motif (C2A/SDPYVK:AAAA, C2A/SDPAAA:AAAA, or C2A/SDPYVK:EEEE) results in $\mathrm{D} \beta \mathrm{H}$ cell surface staining levels comparable with that in cells injected with Texas Red alone or coinjected with control GST preparations (Fig. 5B). This result contrasts dramatically with the inhibitory effect of recombinant $\mathrm{C} 2 \mathrm{~A}$ fragments containing a wild-type polylysine motif on neurotransmitter release from injected PC12 cells (compare with C2A/SDPYVK, C2A/R233Q, and C2A/D230N;R233Q in Figs. 2, 3). Single or double alanine substitutions of the $\mathrm{C} 2 \mathrm{~A}$ polylysine motif show variable levels of relief on the inhibitory effect of recombinant $\mathrm{C} 2 \mathrm{~A}$ fragments on neurotransmitter release from injected PC12 cells (data not shown). These data suggest that the highly conserved $\mathrm{C} 2 \mathrm{~A}$ polylysine motif is functionally important for the inhibitory effects of recombinant $\mathrm{C} 2 \mathrm{~A}$ fragments in our in vivo secretion assay. Furthermore, the overall basic nature of the $\mathrm{C} 2 \mathrm{~A}$ polylysine motif is critical for this effect.

\section{The polylysine motif functions in a calcium- independent manner to regulate neurotransmitter release}

Our earlier observation that the D230N and R233Q mutations do not reverse the inhibitory effect of recombinant $\mathrm{C} 2 \mathrm{~A}$ fragments containing a wild-type polylysine motif suggests that the $\mathrm{C} 2 \mathrm{~A}$ polylysine motif functions independently of calcium binding and syntaxin 1A interactions to regulate neurotransmitter release from PC12 cells. To test this possibility, we introduced these mutations into recombinant $\mathrm{C} 2 \mathrm{~A}$ fragments containing alanine substitutions in the polylysine motif. We generated two $\mathrm{C} 2 \mathrm{~A}-$ GST fusion proteins containing a single mutation at Arg233 (C2A/AAAA:R233Q) or mutations of both Asp230 and Arg233 (C2A/AAAA:D230N;R233Q). The functional consequences of these mutations were analyzed by examining syntaxin $1 \mathrm{~A}$ interactions and calcium-regulated secretion by microinjection into PC12 cells. As expected, the D230N and R233Q mutations abolished calcium-dependent binding of each recombinant $\mathrm{C} 2 \mathrm{~A}$ fragment to syntaxin 1A (Fig. $6 A$ ). Cells injected with C2A/AAAA: R233Q or C2A/AAAA:D230N;R233Q gave levels of D $\beta H$ cell surface staining comparable with that of cells injected with $\mathrm{C} 2 \mathrm{~A} /$ SDPYVK:AAAA (compare Figs. 5B, 6B) or of control cells either injected with Texas Red alone or coinjected with GST preparations (data not shown). Together, these data suggest that recombinant synaptotagmin $1 \mathrm{C} 2 \mathrm{~A}$ fragments containing an intact polylysine motif selectively impair the calcium-regulated secretory machinery in PC12 cells. Furthermore, the C2A polylysine motif functions independently of calcium binding to regulate neurotransmitter release.

\section{DISCUSSION}

A role for synaptotagmin 1 in calcium-regulated exocytosis is well established (for review, see O'Connor et al., 1994; Südhof and Rizo, 1996). Indeed the calcium-binding properties of synaptotagmin 1 are consistent with those predicted for a calcium sensor in regulated exocytosis (Heidelberger et al., 1994; Chapman et al., 1995). In this study, we demonstrate a role for novel interactions mediated through the polylysine motif of recombinant synaptotagmin $1 \mathrm{C} 2 \mathrm{~A}$ fragments in neurotransmitter release from PC12 cells. Our studies indicate that the C2A polylysine motif functions independently of calcium-mediated events to regulate 


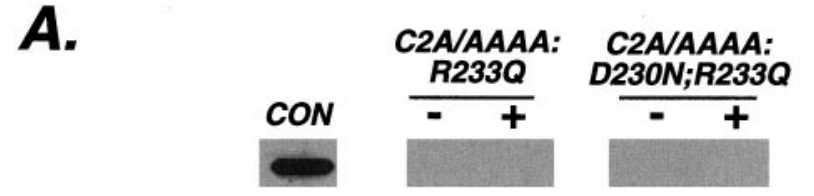

B.

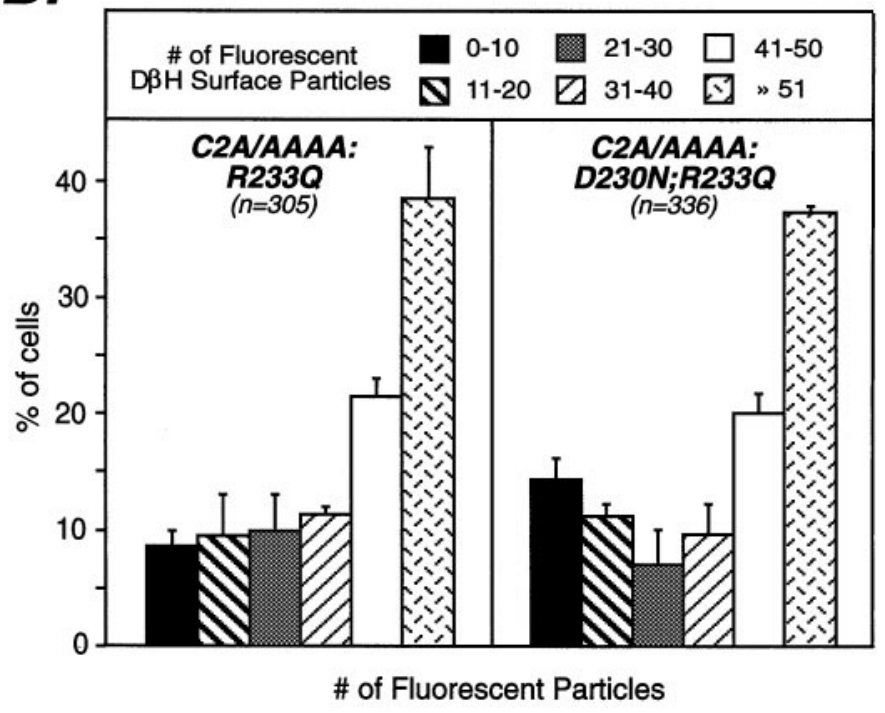

Figure 6. The polylysine motif functions in a calcium-independent manner to regulate neurotransmitter release. $A$, Ten micrograms of the indicated recombinant synaptotagmin $\mathrm{C} 2 \mathrm{~A}$ fragment were incubated with $100 \mu \mathrm{M}$ soluble syntaxin $1 \mathrm{~A}$ in the absence $(-)$ or presence $(+)$ of $3 \mathrm{~mm}$ $\mathrm{CaCl}_{2}$. Syntaxin $1 \mathrm{~A}$ binding was detected by immunoblotting as described in the legend to Figure $2 B$. Seventy-five micromolar fractionated soluble syntaxin (Con) was used as a Western control. No binding was observed using GST-conjugated beads (data not shown). B, NGF-differentiated PC12 cells were coinjected with Texas Red and the indicated soluble recombinant synaptotagmin $\mathrm{C} 2 \mathrm{~A}$ fragment at a final concentration of 0.75 $\mu \mathrm{g} / \mu \mathrm{l}$ and were processed as indicated in the legend to Figure $2 C . \mathrm{D} \beta \mathrm{H}$ staining was quantitated. No statistically significant differences were observed between experimental and control treatments $(p>0.01$, chisquare analysis).

synaptotagmin 1 function in neurotransmitter release. The results from our studies are summarized in Table 1.

The calcium dependency of syntaxin 1A and phospholipid binding to the $\mathrm{C} 2 \mathrm{~A}$ domain suggests an important role for these interactions in synaptotagmin 1 function (Chapman and Jahn, 1994, 1995; Li et al., 1995). Because half-maximal binding of syntaxin $1 \mathrm{~A}$ to the $\mathrm{C} 2 \mathrm{~A}$ domain of synaptotagmin 1 occurs at calcium levels required for vesicle fusion ( $\geq 200 \mu \mathrm{M}$ calcium) (Heidelberger et al., 1994), this interaction may be particularly important for regulating neurotransmitter release by providing a direct means for calcium to regulate vesicle-plasma membrane fusion. Our synaptotagmin 1-syntaxin 1A binding data are consistent with earlier reports (Li et al., 1995; Kee and Scheller, 1996; Shao et al., 1997). However, our observation that mutations in the YVK motif abolish synaptotagmin 1-syntaxin 1A interactions does not agree with those of Chapman et al. (1996). In their studies, deletion of nine amino acids encompassing the YVK motif does not perturb calcium-dependent interactions of recombinant synaptotagmin 1 with native syntaxin $1 \mathrm{~A}$. The differences between these studies may be attributable, in part, to variations in experimental conditions or alternatively to structural limitations imposed by the YVK mutations or deletions on the different recombinant synaptotagmin 1 fragments. Our data and that of others reveal that mutation of Asp230 (D230N) or Arg233 (R233Q) abolishes the calcium-dependent binding of recombinant synaptotagmin $1 \mathrm{C} 2 \mathrm{~A}$ fragments to syntaxin 1A (Sutton et al., 1995; Shao et al., 1997). These findings are consistent with NMR studies on synaptotagmin 1-syntaxin 1A interactions that reveal that calcium binding to the metal coordination site of the C2A domain causes a local electrostatic shift, increasing the affinity of Arg233 for syntaxin 1A (Shao et al., 1997). However, our functional comparison of wild-type and noncalcium/ syntaxin-binding C2A fragments reveals that each blocks calciumregulated secretion when microinjected into neuroendocrine PC12 cells (Table 1). Because recombinant C2A fragments containing the noncalcium-binding mutation D230N also block secretion, it seems that sequestration of intracellular calcium is not responsible for this inhibition. These data should not be extended to suggest that calcium-dependent synaptotagmin 1-syntaxin 1A interactions are not critical in regulating secretory events. It is more likely that the effects of the D230N and R233Q mutations are masked by other functional properties of the C2A domains that are discernible in our in vivo secretion assay. In keeping with this scenario, $\alpha$-latrotoxin overcomes the inhibitory effects of injected recombinant $\mathrm{C} 2 \mathrm{~A}$ fragments, irrespective of their calcium-binding properties, suggesting that these $\mathrm{C} 2 \mathrm{~A}$ fragments function to perturb directly the cellular secretory machinery.

Mutation of a polylysine motif (residues 189-192) distal to the calcium-binding site abolishes the inhibitory effect of injected synaptotagmin $1 \mathrm{C} 2 \mathrm{~A}$ fragments on calcium-regulated secretion (Table 1). The overall basic nature of the $\mathrm{C} 2 \mathrm{~A}$ polylysine motif is important for this inhibitory effect. The inability of injected C2A fragments mutated in the polylysine motif to inhibit secretion was not attributable to injecting insufficient peptide, because a 10 -fold higher concentration $(7.5 \mu \mathrm{g} / \mu \mathrm{l})$ of injected $\mathrm{C} 2 \mathrm{~A}$ fragments similarly failed to inhibit secretion from PC12 cells (data not shown). Our results demonstrating a calcium-independent role for the synaptotagmin $1 \mathrm{C} 2 \mathrm{~A}$ polylysine motif are consistent with other reports. Electrophysiological studies on squid giant presynaptic terminals reveal that microinjection of a 15 amino acid peptide containing the $\mathrm{C} 2 \mathrm{~A}$ polybasic motif reversibly inhibits neurotransmitter release. Conversely, microinjection of an 11 amino acid peptide encompassing two of the five aspartic acid residues (Asp172 and Asp178) important for calcium binding to the C2A domain does not effect neurotransmitter release from squid giant presynaptic terminals (Bommert et al., 1993). Structural studies indicate that the $\mathrm{C} 2 \mathrm{~A}$ polylysine motif is located $\sim 25 \AA$ from the calcium-binding site (Sutton et al., 1995). Because the C2A domain of synaptotagmin 1 does not undergo detectable conformational changes after binding calcium, it is unlikely that calcium binding directly influences molecular events involving regions of the $\mathrm{C} 2 \mathrm{~A}$ domain distal to the calcium coordination site. Taken together, these studies indicate that distinct calcium-independent events mediated through the $\mathrm{C} 2 \mathrm{~A}$ polylysine motif confer novel properties on synaptotagmin 1 function during neurotransmitter release from neuroendocrine and neural cells.

The second $\mathrm{C} 2$ (C2B) domain of synaptotagmin 1 contains a similar polylysine sequence, yet microinjection of recombinant $\mathrm{C} 2 \mathrm{~B}$ fragments or anti-C2B antibodies does not affect neurotransmitter release from PC12 cells, adrenal chromaffin cells, or squid giant presynaptic terminals (Elferink et al., 1993; Fukada et al., 1995; Ohara-Imaizumi et al., 1997). Interestingly, a 20 amino acid 


\begin{tabular}{lcc}
\hline Table 1. Functional comparison of wild-type and mutant synaptotagmin 1 C2A fragments & \\
Recombinant C2A fragment & $\begin{array}{l}\mathrm{Ca}^{2+} \text {-dependent } \\
\text { phospholipid binding }\end{array}$ & $\begin{array}{l}\mathrm{Ca}^{2+} \text {-dependent } \\
\text { syntaxin binding }\end{array}$ \\
\hline C2A/SDPYVK & + & + \\
C2A/SDPAAA & - & - \\
C2A/D230N & ND & - \\
C2A/D230N; R233Q & ND & + \\
C2A/SDPYVK:AAAA & + & - \\
C2A/SDPAAA:AAAA & - & + \\
C2A/SDPYVK:EEEE & + & - \\
C2A/AAAA:D230N & ND & - \\
C2A/AAAA:D230N; R233Q & ND & - \\
\hline
\end{tabular}

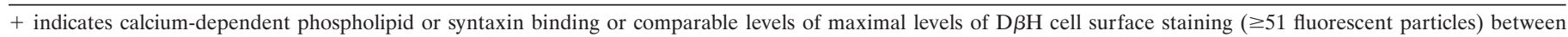

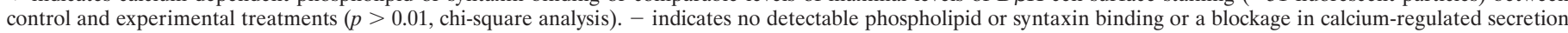

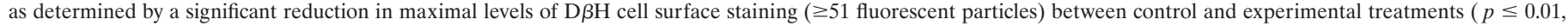
chi-square analysis). ND, Not determined.

peptide encompassing the $\mathrm{C} 2 \mathrm{~B}$ polylysine motif rapidly inhibits neurotransmitter release from microinjected squid terminals (Bommert et al., 1993). These differences may reflect the inability of the C2B peptide to reproduce faithfully the structural properties of the $\mathrm{C} 2 \mathrm{~B}$ domain. Inositol-1,3,4,5-tetrabisphosphate $\left(\mathrm{IP}_{4}\right)$, a modulator of intracellular calcium, binds directly to the $\mathrm{C} 2 \mathrm{~B}$ polylysine motif of recombinant squid synaptotagmin in a calcium-independent manner. $\mathrm{IP}_{4}$ binding has not been demonstrated with the C2A domain (Fukada et al., 1995). $\mathrm{IP}_{4}$ is a potent inhibitor of neurotransmitter release when injected into squid giant presynaptic terminals. Because the inhibitory action of $\mathrm{IP}_{4}$ on neurotransmitter release is abolished by coinjection of anti$\mathrm{C} 2 \mathrm{~B}$ antibodies, calcium-independent $\mathrm{IP}_{4}-$ synaptotagmin $\mathrm{C} 2 \mathrm{~B}$ interactions may be important for synaptic transmission (Fukada et al., 1995). Therefore, despite strong sequence similarities, the polylysine motifs in the $\mathrm{C} 2 \mathrm{~A}$ and $\mathrm{C} 2 \mathrm{~B}$ domains of synaptotagmin contain specialized calcium-independent functional properties required for neurotransmitter release.

The recent identification of nine additional synaptotagmin isoforms in rat brain with different calcium-binding properties suggests that they may play distinct roles in neurotransmitter release (Li et al., 1995; von Poser et al., 1997). Indeed, in cultured hippocampal neurons from mice with mutated synaptotagmin 1 , only the fast component of calcium-regulated secretion is impaired, whereas the slow component is unaffected (Geppert et al., 1994; Goda and Stevens, 1994). Calcium-regulated secretion persists in synaptotagmin 1-deficient PC12 cells, although the overall amount of evoked ATP and catecholamine release is increased (Shoji-Kasai et al., 1992). These studies suggest that calcium sensing by synaptotagmin 1 functions in a background of other calcium-sensing molecules to regulate neurotransmitter release from neural and neuroendocrine cells. Therefore, the contribution from other calcium-binding synaptotagmins cannot be dismissed. However, given our present data demonstrating a calcium-independent activity for the synaptotagmin $1 \mathrm{C} 2 \mathrm{~A}$ domain in neurotransmitter release, the contribution of the noncalcium-binding synaptotagmin isoforms in neurosecretion (e.g., synaptotagmins 4 and 10) should also be considered.

In conclusion, we have provided evidence that extends the functional importance of the C2A domain of synaptotagmin 1 in calcium-regulated exocytosis from neuroendocrine PC12 cells. Most noteworthy is the conclusion that distinct calciumindependent events mediated through the $\mathrm{C} 2 \mathrm{~A}$ polylysine motif confer important functional properties on synaptotagmin 1 dur- ing regulated secretion. Our studies coupled with structural data on the $\mathrm{C} 2 \mathrm{~A}$ domain suggest that the $\mathrm{C} 2 \mathrm{~A}$ domain of synaptotagmin 1 functions as a "janus-faced" molecule, with calciumbinding and calcium-independent interfaces, to control neurotransmission (Südhof and Rizo, 1996; von Poser et al., 1997). Whether these distinct calcium-binding and calcium-independent activities function in concert to regulate synaptotagmin 1 function and trigger neurosecretion or, alternatively, regulate specific, sequential events leading to neurotransmitter release remains to be determined. A more detailed understanding of these properties will contribute greatly to our understanding of synaptotagmin 1 function and its role as a calcium sensor in neurotransmission.

\section{REFERENCES}

Bennett MK, García-Arrarás JE, Elferink LA, Peterson K, Fleming AM, Hazuka CD, Scheller RH (1993) The syntaxin family of vesicular transport receptors. Cell 74:863-873.

Bommert K, Charlton MP, DeBello WM, Chin GJ, Betz H, Augustine GJ (1993) Inhibition of neurotransmitter release by C2-domain peptides implicates synaptotagmin in exocytosis. Nature 363:163-165.

Broadie K, Bellen HJ, DiAntonio A, Littleton JT, Schwarz TJ (1994) Absence of synaptotagmin disrupts excitation-secretion coupling during synaptic transmission. Proc Natl Acad Sci USA 91:10727-10731.

Brose N, Petrenko AG, Südhof TC, Jahn R (1992) Synaptotagmin: a calcium sensor on the synaptic vesicle surface. Science 256:1021-1025.

Chapman ER, Jahn R (1994) Calcium dependent interactions of the cytoplasmic region of synaptotagmin with membranes. J Biol Chem 269:5735-5741.

Chapman ER, Hanson PI, An S, Jahn R (1995) $\mathrm{Ca}^{2+}$ regulates the interaction between synaptotagmin and syntaxin. J Biol Chem 270:23667-23671.

Chapman ER, An S, Edwardson JM, Jahn R (1996) A novel structure for the second $\mathrm{C} 2$ domain of synaptotagmin. J Biol Chem 271:5844-5849.

Coussens L, Parker PJ, Rhee L, Yang-Feng TL, Chen E, Waterfield MD, Franke U, Ulrich A (1986) Multiple distinct forms of bovine and human protein kinase $\mathrm{C}$ suggest diversity on cellular signaling pathways. Science 233:859-866.

Davletov BA, Südhof TC (1993) A single $C_{2}$ domain from synaptotagmin I is sufficient for high affinity $\mathrm{Ca}^{2+} /$ phospholipid binding. J Biol Chem 268:26383-26390.

DeBello WM, Betz H, Augustine GJ (1993) Synaptotagmin and neurotransmitter release. Cell 74:947-950.

Elferink LA, Peterson MR, Scheller RH (1993) A role for synaptotagmin (p65) in regulated exocytosis. Cell 72:153-159.

Fukada M, Moreira JE, Lewis FMT, Sugimori M, Niinobe M, Mikoshiba K, Llinas R (1995) Role of the C2B domain of synaptotagmin in vesicular release and recycling as determined by specific antibody injection into the squid giant synapse preterminal. Proc Natl Acad Sci USA 92:10708-10712. 
Geppert M, Goda Y, Hammer RE, Li C, Rosahl TW, Stevens CF, Südhof TC (1994) Synaptotagmin I: a major $\mathrm{Ca}^{2+}$ sensor for transmitter release at a central synapse. Cell 79:717-727.

Goda Y, Stevens CF (1994) Two components of transmitter release at a central synapse. Proc Natl Acad Sci USA 91:12942-12946.

Guan K, Dixon JE (1991) Eukaryotic proteins expressed in Escherichia coli: an improved thrombin cleavage and purification procedure of fusion proteins with glutathione $S$-transferase. Anal Biochem 192:262-267.

Hata Y, Davletov B, Petrenko AG, Jahn R, Südhof TC (1993) Interaction of synaptotagmin with the cytoplasmic domains of neurexins. Neuron 10:307-315.

Heidelberger R, Heinemann C, Matthews G (1994) Calcium dependence of the rate of exocytosis in a synaptic terminal. Nature 366:347-351.

Kee Y, Scheller RH (1996) Localization of synaptotagmin-binding domains on syntaxin. J Neurosci 16:1975-1981.

Krasnoperov VG, Bittner MA, Beavis R, Kuang Y, Salinikow KV, Chepnurny OG, Little AR, Plotnikov AN, Wu D, Holz R, Petrenkko AG (1997) $\alpha$-Latrotoxin stimulates exocytosis by the interaction with a neuronal G-protein-coupled receptor. Neuron 18:925-937.

Lang J, Fukada M, Zhang H, Mikoshiba K, Wollheim CB (1997) The first $\mathrm{C} 2$ domain of synaptotagmin 1 is required for exocytosis of insulin from pancreatic $\beta$-cells: action of synaptotagmin at low micromolar calcium. EMBO J 16:5837-5846.

Lelianova VG, Davletov BA, Sterling A, Rahman MA, Grishin EV, Tooty NF, Ushkaryov YA (1997) $\alpha$-Latrotoxin receptor, latrophilin, is a novel member of the secretin family of $\mathrm{G}$ protein-coupled receptors. J Biol Chem 272:21504-21508.

Li C, Takei K, Geppert M, Daniell L, Stenius K, Chapman ER, Jahn R, De Camilli P, Südhof TC (1994) Synaptic targeting of rabphillin-3A, a synaptic vesicle calcium/phospholipid-binding protein, depends on $\operatorname{rab3A/3C.~Neuron~13:885-898.~}$

Li C, Ullrich B, Zhang JZ, Anderson RGW, Brose N, Südhof TC (1995) $\mathrm{Ca}^{2+}$-dependent and -independent activities of neural and non-neural synaptotagmins. Nature 375:594-599.

Littleton JT, Stern M, Perin M, Bellen HJ (1994) Calcium dependence of neurotransmitter release and rate of spontaneous vesicle fusions are altered in Drosophila synaptotagmin mutants. Proc Natl Acad Sci USA 91:10888-10892.

Mikoshiba K, Fukada M, Moreira JE, Lewis FMT, Sugimora M, Niinobe M, Llinas R (1995) Role of the C2A domain of synaptotagmin in transmitter release as determined by specific antibody injection into the squid giant synapse preterminal. Proc Natl Acad Sci USA 92:10703-10707.

Niinobe M, Yamaguhi Y, Fukada M, Mikoshiba K (1994) Synaptotagmin is an inositol polyphosphate binding protein: isolation and char- acterization as an Ins 1,3,4,5- $\mathrm{P}_{4}$ binding protein. Biochem Biophys Res Commun 205:1036-1042.

O'Connor V, Augustine GJ, Betz H (1994) Synaptic vesicle exocytosis: molecules and models. Cell 76:785-787.

Ohara-Imaizumi M, Fukada M, Niinobe M, Misonou H, Ikeda K, Murakami T, Kawasaki M, Mikoshiba K, Kumakura K (1997) Distinct roles of $\mathrm{C} 2 \mathrm{~A}$ and $\mathrm{C} 2 \mathrm{~B}$ domains of synaptotagmin in the regulation of exocytosis in adrenal chromaffin cells. Proc Natl Acad Sci USA 94:287-291.

Orita S, Sasaki T, Naito A, Komuro R, Ohtsuka T, Maeda M, Suzuki H, Igarashi H, Takai Y (1995) Doc2: a novel brain protein having two repeated C2-like domains. Biochem Biophys Res Commun 206:439-448.

Perin MS, Fried VA, Mignery GA, Jahn R, Südhof TC (1990) Phospholipid binding by a synaptic vesicle protein homologous to the regulatory region of protein kinase C. Nature 345:260-263.

Rosenthal L, Zacchetti D, Madeddu L, Meldosi J (1990) Mode of action of $\alpha$-latrotoxin: role of divalent cations in $\mathrm{Ca}^{++}$-dependent and $\mathrm{Ca}^{++}$ independent effects mediated by the toxin. Mol Pharmacol 38:917-923.

Schivell AE, Batchelor RH, Bajjalieh SM (1996) Isoform-specific, calcium regulated interaction of the synaptic vesicle protein SV2 and synaptotagmin. J Biol Chem 271:27770-27775.

Shao X, Davletov BA, Sutton RB, Südhof TC, Rizo J (1996) Bipartite $\mathrm{Ca}^{2+}$-binding motif in $\mathrm{C} 2$ domains of synaptotagmin and protein kinase C. Science 273:248-251.

Shao X, Li C, Fernandez I, Zhang X, Südhof TC, Rizo J (1997) Synaptotagmin-syntaxin interaction: the $\mathrm{C} 2$ domain as a $\mathrm{Ca}^{2+}$-dependent electrostatic switch. Neuron 18:133-142.

Shoji-Kasai Y, Yoshida A, Sato K, Hoshino T, Ogura A, Kondo S, Fujimoto Y, Kuwahara R, Kato R, Takahashi M (1992) Neurotransmitter release from synaptotagmin-deficient clonal variants of PC12 cells. Science 256:1820-1823.

Südhof TC, Rizo J (1996) Synaptotagmins: $C_{2}$-domain proteins that regulate membrane traffic. Neuron 17:379-388.

Sugita S, Hata Y, Südhof TC (1996) Distinct calcium dependent properties of the first and second C2-domains of synaptotagmin 1. J Biol Chem 271:1262-1265.

Sutton RB, Davletov BA, Berghuis AM, Südhof TC, Sprang SR (1995) Structure of the first $\mathrm{C} 2$ domain of synaptotagmin 1: a novel $\mathrm{Ca}^{2+}$ phospholipid-binding fold. Cell 80:929-938.

von Poser C, Ichtchenko K, Shao X, Rizo J, Südhof TC (1997) The evolutionary pressure to inactivate. J Biol Chem 272: 14314-14319.

Zhang JZ, Davletov BA, Südhof TC, Anderson RGW (1994) Synaptotagmin 1 is a high affinity receptor for clathrin AP-2: implications for membrane recycling. Cell 78:751-760. 